\title{
Plant Oil Emulsions Prevent Senescent Scald and Core Breakdown and Reduce Fungal Decay in 'Bartlett' Pears
}

\author{
Zhiguo Ju and Eric A. Curry \\ U.S. Department of Agriculture, Agricultural Research Service, Tree Fruit Research Laboratory, 1104 \\ N. Western Ave., Wenatchee, WA 98801 \\ Yousheng Duan, Zhiqiang Ju, and Aixin Guo \\ Department of Research and Development, Zibo Wanquan Co., Shandong, China
}

AdDitional INDEX wORDs. ethylene, volatile, ripening, Pyrus communis

\begin{abstract}
Preclimacteric 'Bartlett' pears (Pyrus communis L.) were dipped for 3 min in either corn (Zea mays L.) or soybean [(Glycine $\max \left(\mathrm{L}\right.$.) Merrill] oil emulsion immediately after harvest and stored at $0{ }^{\circ} \mathrm{C}$. Untreated control fruit developed higher percentages of senescent scald, core breakdown, and decay after 15 weeks storage. Both treatments inhibited senescent scald, core breakdown, and decay in a similar and concentration dependent manner. Complete control of senescent scald and core breakdown was achieved by emulsions at $5 \%$ and $10 \%$, and of decay by emulsion at $10 \%$. Compared with controls, emulsion treatments delayed and reduced internal ethylene accumulation and volatile production in early storage and increased them in late storage. Compared with controls, fruit treated with oil contained similar levels of internal $\mathrm{O}_{2}$ and $\mathrm{CO}_{2}$ in early storage and higher $\mathrm{CO}_{2}$ and lower $\mathrm{O}_{2}$ in late storage. While control fruit lost commercial value after 15 weeks at $0{ }^{\circ} \mathrm{C}$ plus 5 days at $20^{\circ} \mathrm{C}$, oil-treated fruit exhibited normal color change, and had higher soluble solids, titratable acidity, and volatile production. Microscopic examination revealed that emulsion-treated fruit had a continuous surface film conforming to the contour of the fruit.
\end{abstract}

'Bartlett' is one of the major pear (Pyrus communis) cultivars in the United States and has a relatively short storage life (Kupferman, 1998). Under regular storage conditions, fruit may fail to ripen normally if stored for an extended time, and may develop physiological disorders such as senescent scald and core breakdown within 1 or 2 months (Blanpied, 1975; Meheriuk, 1990; Meheriuk et al., 1994). In addition, decay develops rapidly when fruit start to senesce. Annual losses due to storage disorders and decay of pears in the Pacific Northwest United States are $\approx 20 \%$ of the crop. Currently, the only means for preventing the above disorders and decay are by reducing time in storage (Meheriuk et al., 1994) and using fungicides. Fungicide application to food or food products, however, is facing increasing challenges in recent years due to increases in resistant strains, in addition to tightened regulations and increased public concern regarding food safety (Aked, 1997; National Research Council, 1987). As a result, certain fungicides for postharvest use have been withdrawn from the market, and regulation of new fungicides has become more time consuming and expensive. Furthermore, because fungicides are generally not permitted on fruit marketed as organic, effective alternatives to fungicide use would be highly beneficial to the fruit industry.

Edible plant oil treatments have been effective in controlling superficial scald in 'Delicious' and 'Granny Smith' apples [Malus sylvestris (L.) Mill. Var.domestica (Borkh.) Mansf.] and 'd'Anjou' pears (Ju and Curry, 2000; Ju et al., 2000) and in reducing severity of fungal decay in 'Delicious' apples and 'Ya Li' pear (Duan et al., 2000) and 'd'Anjou' pears (Ju and Curry, 2000). While superficial scald in apples and 'd'Anjou' pears may be associated with $\alpha$-farnesene oxidation, senescent scald and core breakdown in 'Bartlett' pears are senescent related (Meheriuk et al., 1994),

Received for publication 15 June 2000. Accepted for publication 1 Feb. 2001. The cost of publishing this paper was defrayed in part by the payment of page charges. Under postal regulations, this paper therefore must be hereby marked advertisement solely to indicate this fact. and the effects of plant oil emulsion on senescence-related disorders have not been studied. Modified internal atmosphere has been suggested as the mechanism for inhibiting ethylene production and delaying fruit ripening in wax or other polymercoated fruit (Hagenmaier and Shaw, 1992; Saftner, 1999). The effects of plant oil treatment on the physical characteristics of fruit cuticle and the internal atmosphere of fruit, however, have not been studied. Our objective, therefore, was to study the effects and possible mechanism of oil treatments on senescent scald, core breakdown, and decay in 'Bartlett' pears.

\section{Materials and Methods}

Plant material and treatments. The first experiment was conducted in China in 1997 and repeated in 1998, using 'Bartlett' pears harvested at commercial maturity. Refined corn (Zea Mays) or soybean (Glycine max) oil emulsions were prepared by mixing plant oil, Tween 60 , and water at $90{ }^{\circ} \mathrm{C}$ (Ju et al., 2000). Each treatment contained three replications with 160 fruit each. Since dipping fruit in water may increase fungal activity through spore transference, nontreated fruit were used as controls. At harvest, fruit were dipped in 5\% and $10 \%$ corn and soybean oil emulsions, respectively, for $3 \mathrm{~min}$, placed in cardboard boxes, and stored at $0{ }^{\circ} \mathrm{C}$. Ten fruit from each replication were removed from storage every 3 weeks up to 15 weeks and used individually for measurements of internal ethylene, $\mathrm{O}_{2}$, and $\mathrm{CO}_{2}$ immediately upon removal. The remaining fruit were evaluated for storage disorders, decay, and quality attributes after 15 weeks at $0{ }^{\circ} \mathrm{C}$ plus $5 \mathrm{~d}$ at 20 ${ }^{\circ} \mathrm{C}$. A sensory evaluation of taste and flavor was also conducted by informal panels.

The second experiment was conducted in the United States in 1999. 'Bartlett' fruit were harvested from two commercial orchards in Wenatchee, Wash. Fruit from the first orchard were harvested 23 Aug. and treated with $10 \%$ refined corn oil with nontreated fruit serving as controls. Fruit from the second orchard 
were harvested 1 Sept. and treated with $1 \%, 3 \%, 5 \%$, or $10 \%$ refined corn oil also with nontreated fruit serving as controls. Each treatment contained three replications of 160 fruit. After treatment, fruit were placed in two cardboard boxes and stored in air at $0{ }^{\circ} \mathrm{C}$. Ethylene and volatile production were measured immediately after removal from cold storage every 3 weeks for 15 weeks. Flesh firmness, acidity, skin color, and soluble solids content (SSC) were measured at harvest and after 15 weeks storage plus $5 \mathrm{~d}$ at $20^{\circ} \mathrm{C}$. Senescent scald, core breakdown, and decay were evaluated after 15 weeks storage plus $3 \mathrm{~d}$ at $20^{\circ} \mathrm{C}$. A sensory evaluation of taste and flavor was also conducted by informal panels.

A third experiment was conducted in 2000 to evaluate the effects on fruit ripening of the surfactant used in the formulation of the oil emulsion. Fruit were harvested from experimental orchards of Washington State University at Columbia View, near Orondo, Wash., on 14 Aug. The same day, they were dipped in $0.5 \%$ or $1 \%$ Tween 60 or $5 \%$ (containing $0.5 \%$ Tween 60 ) and $10 \%$ (containING 1\% Tween 60) oil emulsions, respectively, with nontreated fruit serving as the control. Each treatment contained three replications of 80 fruit. Fruit were placed on paper trays, put in cardboard boxes, and held at $20^{\circ} \mathrm{C}$ for $20 \mathrm{~d}$. Internal ethylene, flesh firmness, and skin color were evaluated every $4 \mathrm{~d}$ using 15 fruit from each replication.

MEASUREMENT OF FRUIT COLOR, FIRMNESS, SOLUBLE SOLIDS CONTENT, AND TITRITABLE ACIDITY. Fruit color, firmness, soluble solids content (SSC), and titratable acidity (TA) were quantified using three replications of 10 fruit. Fruit color at harvest was measured using a colorimeter (DP-301; Minolta, Osaka, Japan), taking three readings per fruit. Since the peel of control fruit as well as some oil-treated fruit turned brown or dark brown after storage, skin color was evaluated and recorded as brown, partially brown, or yellow instead of using values derived from equipment. Firmness was measured with an electronic pressure tester (EPT1, Lake city Tech. Products, Inc., Kelowna B.C., Canada) equipped with an 8-mm tip. Readings were made on two paired sides of each fruit. SSC was assessed with a digital refractometer (PR-1, Atago Co. Ltd., Japan) on a combined sample of juice extracted from 10 fruit in each replication. TA was measured by titrating 5 $\mathrm{mL}$ of juice extracted from 10 fruit in each replication using a standard pH meter (PHM 82, Radiometer American) in conjunction with a titrator (TTT 80, Radiometer American) and expressed as percent malic acid equivalents.

Evaluation OF SENESCENT SCALD, CORE BREAKDOWN, AND DECAY. Senescent scald was defined as a dark discoloration on fruit skin, and core breakdown as a brown, watery discoloration in the flesh or core area (Meheriuk et al., 1994). Senescent scald, core breakdown, and decay were recorded as percent incidence.

Sensory EVAluation OF TASTE AND Flavor. A panel of five experienced individuals was employed to conduct the evaluation. Taste and flavor were rated on a 1 to 4 scale, where $1=$ poor, $2=$ fair, 3 = good, and $4=$ excellent.

INTERNAL ETHYLENE, $\mathbf{C O}_{2}$, AND $_{2}$ MEASUREMENT. A sample of gas from whole fruit was obtained according the method of Beyer and Morgan (1970). A gas chromatograph (HP 6890; Hewlett Packard, Bellevue, Wash. $)$ equipped with a glass column $(610 \times 3.2 \mathrm{~mm}$ i.d. $)$ packed with Porapak Q (90-100 mesh) was used. Oven, injector, and flame ionization detector temperatures were 50,50 , and $200^{\circ} \mathrm{C}$, respectively, for ethylene and 115,115 , and $200^{\circ} \mathrm{C}$ for ethanol. Gas flows for $\mathrm{N}_{2}$ carrier, $\mathrm{H}_{2}$, and air were 30,30 , and $300 \mathrm{~mL} \cdot \mathrm{min}^{-1}$, respectively.

Volatile PRODUCTION MEASUREMENT. Gas chromatographymass spectrometry (GC-MS) with a solid-phase-microextraction (SPME) method as described previously (Ju and Curry, 2000) was used to measure $\alpha$-farnesene and volatiles. Six fruit from each replication were placed in a $4-\mathrm{L}$ glass jar at $20^{\circ} \mathrm{C}$. The jars were connected to a flow-through system with a flow rate of 100 $\mathrm{mL} \cdot \mathrm{min}^{-1}$. After a 2-h equilibration, $0.5 \mathrm{~mL}$ air was taken for ethylene and, at the same time, a $100 \mathrm{~mm}$ polydimethylsiloxane (PDMS) probe (Supelco, Bellefonte, Pa.) was introduced into each jar and allowed to adsorb volatiles for $10 \mathrm{~min}$. The probe was inserted immediately into the injection port of a gas chromatograph (HP 5890, Hewlett Packard, San Fernando, Calif.). Adsorbed volatiles were allowed to desorb for $3 \mathrm{~min}$ in the injector with a constant temperature of $250{ }^{\circ} \mathrm{C}$. The oven temperature was increased from $35^{\circ} \mathrm{C}$ to $250{ }^{\circ} \mathrm{C}$ at a rate of $50{ }^{\circ} \mathrm{C} \cdot \mathrm{min}^{-1}$ and then held for $4 \mathrm{~min}$. Helium was used as carrier gas and the head pressure was maintained to give a constant flow rate of $1 \mathrm{~mL} \cdot \mathrm{min}^{-1}$. Analysis was conducted using a Hewlett Packard wide bore capillary column (30 $\mathrm{m}$ length $\times 0.25 \mathrm{~mm}$ i.d.) with a splitless injection. Volatiles were identified by analysis of fragmentation profiles using a MS detector (model 5971; Hewlett Packard) combined with confirmatory library matches. Only the six major peaks, butyl butanoate, hexyl acetate, hexyl propanoate, butyl hexanoate, hexyl butyrate, hexyl hexanoate, and $\alpha$-farnesene were quantified using standards (Sigma, St. Louis, Mo.) and presented as $\mathrm{mmol} \cdot \mathrm{kg}^{-1} \cdot \mathrm{h}^{-1}$ of total esters. $\alpha$ Farnesene was quantified using the abundance of characteristic ion 93 and reported as units per kilogram fresh weight per hour. A reading of 1000 in abundance was defined as one unit.

MICROSCOPY OF FRUIT SURFACE FROM OIL-TREATED AND NON-

Table 1 . Effects of refined corn and soybean oil treatment on fruit quality attributes and storage disorders in 'Bartlett' pears after 15 weeks at $0{ }^{\circ} \mathrm{C}$ and $5 \mathrm{~d}$ at $20^{\circ} \mathrm{C}$.

\begin{tabular}{|c|c|c|c|c|c|c|c|c|}
\hline Treatment & $\begin{array}{l}\text { Firmness } \\
(\mathrm{N})\end{array}$ & $\begin{array}{c}\text { Acidity } \\
(\% \text { malic acid })\end{array}$ & $\begin{array}{l}\text { Skin } \\
\text { color }\end{array}$ & $\begin{array}{l}\mathrm{SSC} \\
(\%)\end{array}$ & $\begin{array}{c}\text { Scald } \\
(\%)\end{array}$ & $\begin{array}{c}\text { Breakdown } \\
(\%)\end{array}$ & $\begin{array}{l}\text { Decay } \\
(\%)\end{array}$ & Sensory \\
\hline Control & 43 & 0.29 & Brown & 11.2 & 76 & 97 & 46 & 1.2 \\
\hline Oil, $1 \%$ & 45 & 0.28 & Brown & 11.4 & 78 & 94 & 49 & 2.7 \\
\hline Oil, 3\% & 40 & 0.32 & Partial brown & 11.9 & 14 & 16 & 27 & 3.1 \\
\hline Oil, $5 \%$ & 41 & 0.37 & Yellow & 12.5 & 0 & 0 & 7 & 3.6 \\
\hline Oil, $10 \%$ & 37 & 0.39 & Yellow & 12.9 & 0 & 0 & 0 & 3.9 \\
\hline \multicolumn{9}{|l|}{ Significant } \\
\hline Linear & NS & $* * * *$ & & $* * * *$ & $* * * *$ & $* * * *$ & $* * * *$ & $* * * *$ \\
\hline Quadratic & NS & NS & & NS & NS & NS & NS & NS \\
\hline
\end{tabular}

$\overline{{ }^{\mathrm{Z}} \text { Results were similar between corn oil and soybean oil at the same concentration, among different seasons, and between experiments in China and }}$ the United states and therefore, data are means from these experiments.

Ns,***** Nonsignificant or significant at $P \leq 0.0001$, respectively. 
TREATED FRUIT. Pears used for microscopic examination were treated by holding fruit by the stem and calyx ends and dipping half of the fruit, longitudinally, in a 10\% corn oil emulsion for $3 \mathrm{~min}$. After allowing the fruit to air-dry for $60 \mathrm{~min}$, it was carefully placed in a cardboard box in regular storage for $21 \mathrm{~d}$. Peel samples $\approx 0.8 \mathrm{~mm}$ thick and $3 \mathrm{~mm}$ in diameter were excised by hand from treated and nontreated areas of the same pear at the same equatorial diameter using a double-edged razor blade, and placed on a $12 \mathrm{~mm}$ doublesided carbon adhesive tab affixed to a standard $12 \mathrm{~mm}$ aluminum specimen mount. The mount containing the tissue sections was placed on a rotating sample holder in the chamber of a sputter coater (Desk II; Denton Vaccum, Middleton, N.J.) and gold-coated for 45 $\mathrm{s}$ at an anode current of $45 \mathrm{ma}$. Electron micrographs were generated using a scanning electron microscope (S-530; Hitachi, Palo Alto, Calif.) equipped with a super eucentric stage tilted to $60^{\circ}$, and a PCI digital interface board (Quartz Imaging Corp., Vancouver, B.C., Canada). Tissue was imaged using an accelerating voltage of $25 \mathrm{kV}$ at a resolution of $2048 \times 1536$ pixels.

Statistical analysis. Data were subjected to analysis of variance and regression procedures using SAS Statistical Software (SAS Inst. Inc., Cary, N.C.). Means were separated using Tukey's studentized range test (HSD). Only results significant at $P \leq 0.05$ are discussed.

\section{Results}

EFFECTS OF OIL TREATMENT ON SENESCENT SCALD, CORE BREAKDOWN, AND DECAY. NO differences were found between corn oil and soybean oil when applied at the same concentration. Similar trends were found both among different seasons and between experiments in China and the United States and therefore, data presented in Table 1 are means of the same concentration from these experiments. After 15 weeks storage at $0{ }^{\circ} \mathrm{C}$, nontreated fruit developed high percentages of senescent scald, core breakdown, and decay. Oil treatments inhibited senescent scald, core breakdown, and decay in a concentration dependent manner. Complete control of scald and core breakdown was achieved by $5 \%$ or $10 \%$ oil and of decay by $10 \%$ oil treatment.

EFFECTS OF OIL TREATMENT ON FRUIT COLOR, FLESH FIRMNESS, SSC, TA AND SENSORY CHARACTERISTICS. Compared with controls, oil-treated fruit had similar flesh firmness but higher levels of SSC and TA after 15 weeks at $0{ }^{\circ} \mathrm{C}$ plus $5 \mathrm{~d}$ at $20^{\circ} \mathrm{C}$ (Table 1$)$. The skin color of control fruit was brown or dark brown while that of oil-treated fruit ranged from partially brown at the low oil concentration to yellow at the high concentration. Oil-treated fruit had higher ratings in taste and flavor than controls.

EFFECTS OF OIL TREATMENT ON INTERNAL ETHYLENE, $\alpha$-FARNESENE, AND VOLATILE PRODUCTION. Internal ethylene in nontreated fruit was below detectable levels at harvest, started to rise at 1 week, increased and reached a maximum at 9 weeks, and decreased thereaf- ter (Fig. 1). Oil treatments delayed and reduced accumulation of ethylene in early storage but increased internal ethylene in late storage compared with controls. $\alpha$-Farnesene and total ester production showed trends similar to those of internal ethylene in both oiltreated and control fruit.

EFFECTS OF OIL TREATMENT ON INTERNAL $\mathrm{CO}_{2}$ AND $\mathrm{O}_{2}$. In controls, internal $\mathrm{CO}_{2}$ increased and $\mathrm{O}_{2}$ decreased slowly during storage (Fig. 2). Oil treatments did not affect internal atmosphere in early storage but increased internal $\mathrm{CO}_{2}$ to $6 \mathrm{kPa}$ and reduced internal $\mathrm{O}_{2}$ to $12 \mathrm{kPa}$ by the end of storage.

EFFECTS OF SURFACTANT TREATMENT ON FRUIT RIPENING AND QUALITY ATTRIBUTES. Compared with controls, Tween 60 at $1 \%$ slowed down ethylene production in early storage but not in late storage (Fig. 3). Flesh firmness and skin color were not affected

Fig. 1. Effects of $10 \%$ refined corn oil treatment on (A) internal ethylene concentration and $(\mathbf{B}) \alpha$-farnesene and $(\mathbf{C})$ total ester production in 'Bartlett' pears stored at $0{ }^{\circ} \mathrm{C}$ for 15 weeks. Measurements were made immediately after storage and legend in (A) applies to all figures.
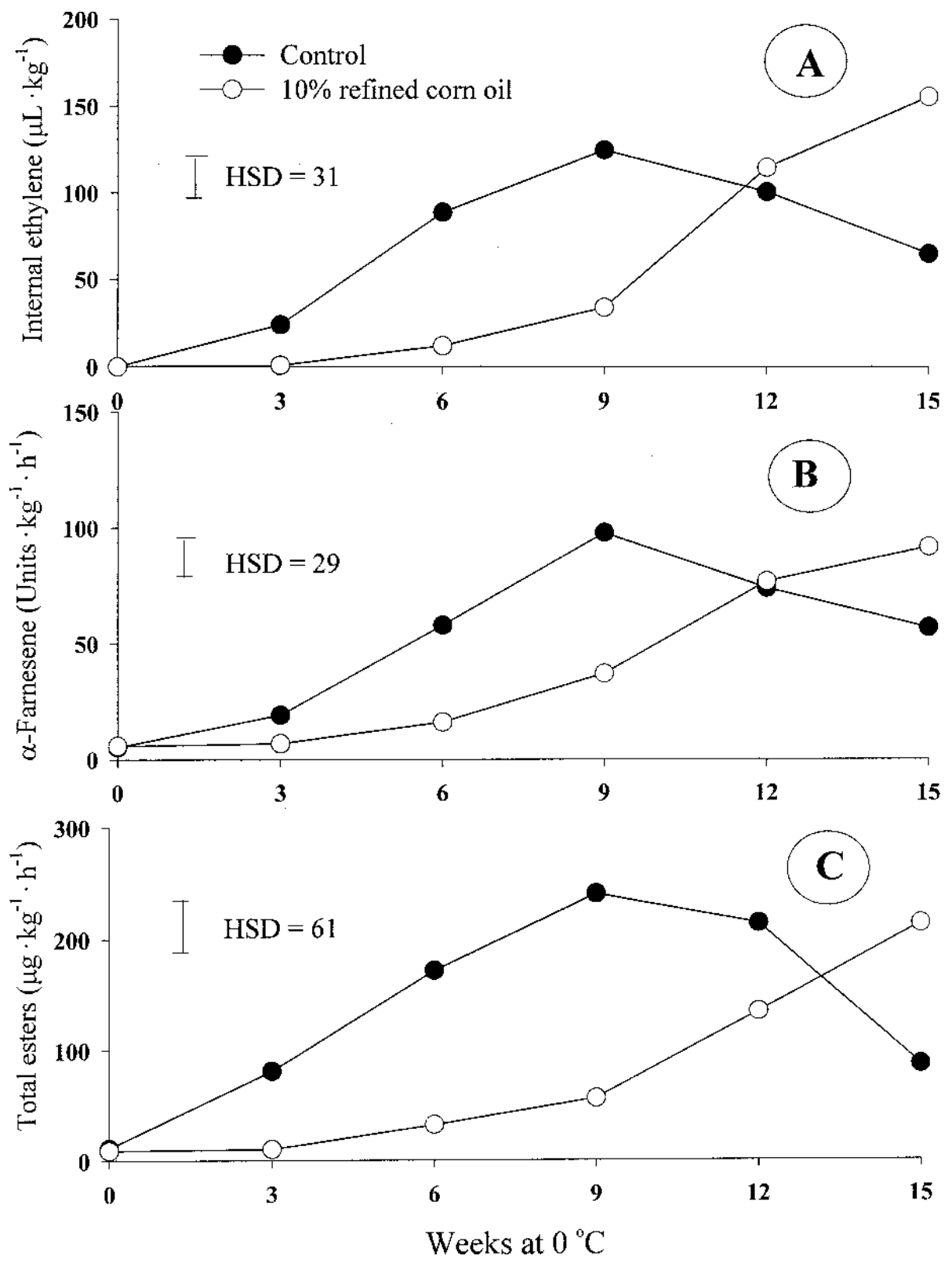

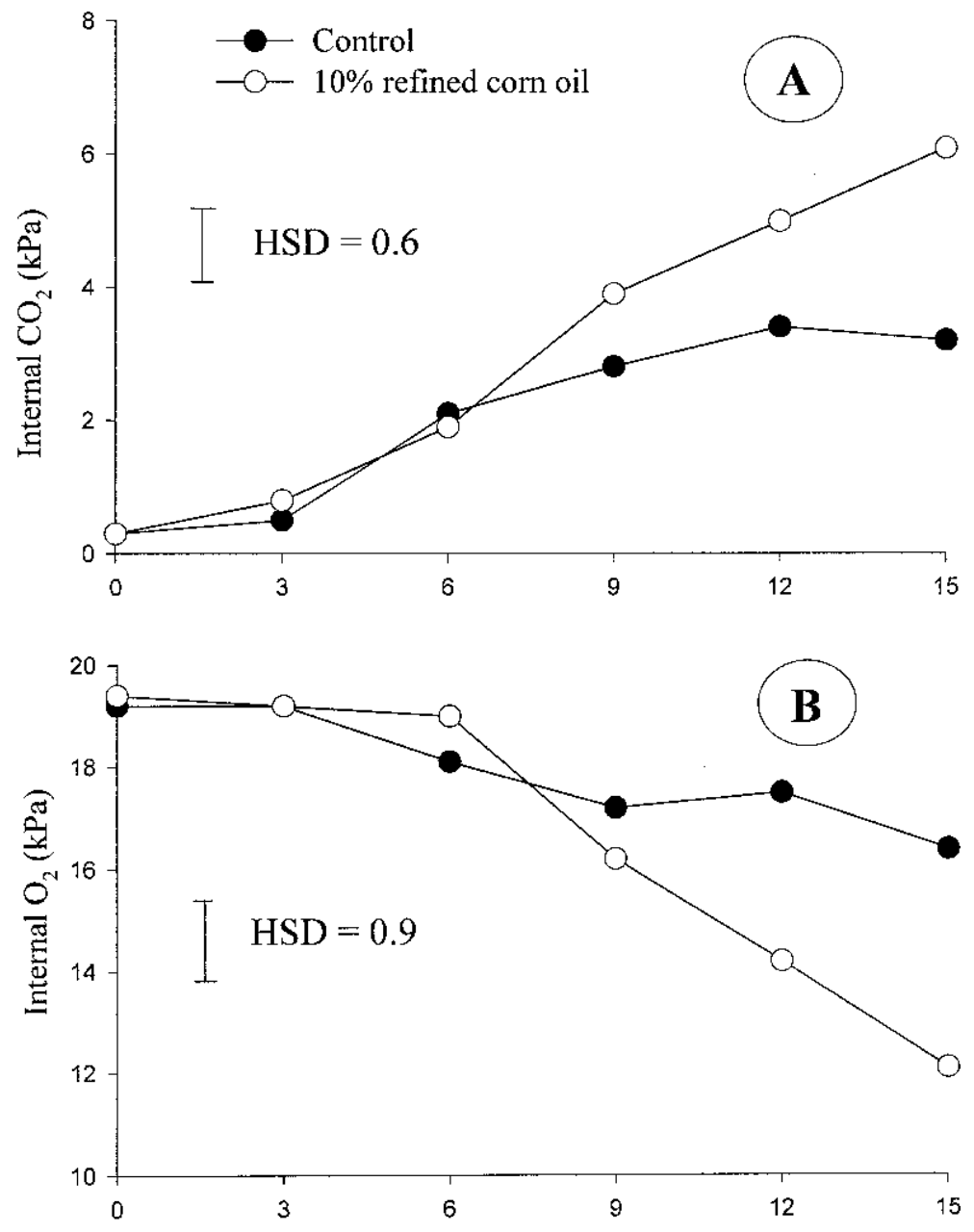

Weeks at $0{ }^{\circ} \mathrm{C}$

was achieved by $10 \%$ oil emulsion. Inhibition of fruit decay by plant oil treatments is consistent with the previous reports in apples and other pear cultivars (Duan et al., 2000; Ju and Curry, 2000). In addition, treated fruit had higher levels of SSC and TA, and produced higher levels of volatiles than nontreated controls by the end of storage. According to sensory evaluation, oil-treated fruit had higher ratings on appearance, taste, and flavor. These data suggest storage life of 'Bartlett' pears was extended from $\approx 2$ to 4 months by oil treatments. Considering the nature of these plant oils, they may become an effective tool in maintaining fruit quality, preventing storage disorders, and reducing decay severity in both organically grown and conventionally produced 'Bartlett' pears.

Senescent scald or core breakdown in 'Bartlett' is associated with fruit ripening and senescence (Meheriuk et al., 1994), and both can be reduced when fruit are stored at lower $\left(-1^{\circ} \mathrm{C}\right)$ temperature (Blanpied, 1975). According to our measurements of ethylene, firmness and TA, reduction of senescent scald and core breakdown in oil-treated fruit is related to delayed fruit senescence due, possibly, to changes in the physical characteristics of the fruit cuticle. Plant oil or oil emulsion applied to the fruit surface appears to seal the minute cracks, lenticels, and other sites of gas diffusion (Fig. 3), either by forming a thin film on the fruit surface or by acting as a surface active agent to dissolve cuticular compounds and alter cuticular structure, thus affecting mass transfer (Fig. 2). In fruit, atmosphere exchange is largely through lenticels, cracks in the fruit cuticle, as well as through the stem and calyx. Cracks in cuticle are 12 times more permeable to water vapor than intact cuticle (Maguire et al., 1999) and, although no supporting data are available, a similar trend is likely for $\mathrm{O}_{2}$ and $\mathrm{CO}_{2}$ permeance. Conceivably, the film formed from the emulsion treatments modified fruit internal atmosphere (Fig. 2) as suggested by other fruit coating experiments (Hagenmaier and Shaw, 1992; Saftner, 1999). However, internal $\mathrm{CO}_{2}$ and $\mathrm{O}_{2}$ concentrations in oil-

Fig. 2. Effects of $10 \%$ refined corn oil treatment on internal (A) $\mathrm{CO}_{2}$ and $(\mathbf{B}) \mathrm{O}_{2}$ concentrations in 'Bartlett' pears stored at $0{ }^{\circ} \mathrm{C}$ for 15 weeks. Measurements were made immediately after storage.

by Tween 60 at either $0.5 \%$ or $1 \%$. Lenticel darkening was observed on $\approx 10 \%$ of Tween 60 (1\%)-treated but not on $0.5 \%$ Tween 60-treated fruit (data not presented) after $20 \mathrm{~d}$ storage at $20{ }^{\circ} \mathrm{C}$. Compared with fruit treated with surfactant alone, fruit treated with the same Tween 60 concentration plus oil emulsion had lower ethylene production, higher flesh firmness and greener skin color. Fruit treated with $10 \%$ oil emulsion containing $1 \%$ Tween 60 did not develop lenticel injury (data not presented).

EFFECTS OF OIL TREATMENT ON PHYSICAL CHARACTERISTICS OF FRUIT CUTICLE. A moderate degree of detail was evident on lenticels and microcracks on nontreated fruit cuticle (Fig. 4A). After dipping in oil emulsion, however, lenticels and cracks were covered by what appeared to be a contiguous film (Fig. 4B).

\section{Discussion}

Treating fruit with corn or soybean oil emulsion reduced senescent scald, core breakdown, and decay in a concentration dependent manner. Complete control of scald and core breakdown was achieved by $>5 \%$ oil emulsion, and control of decay treated fruit at early storage were not affected at the same time that internal ethylene was reduced (Figs. 1 and 2). One possibility is that oil treatments may affect ethylene production by the fruit peel and flesh differently, especially at early storage, and measuring internal atmosphere in a whole fruit may not reflect these differences. Fruit peels produce more ethylene than flesh on both fresh and dry weight bases and the climacteric rise in ethylene is detected earlier in peel than in flesh (Ju and Curry, unpublished data). Since it is the fruit peel that is in direct contact with the oil, it is possible that ethylene production in peel is inhibited immediately after treatment, whereas the body of the cortical tissue requires a longer time to reflect changes in internal atmosphere.

Our results also showed that Tween 60 alone at high concentration (1\%) inhibited ethylene production in pears (Fig. 3). This inhibition is likely through a similar mechanism as discussed above, since dipping fruit in aqueous surfactant solution can modify sublenticel structure resulting in blurring, smoothing out, or reduction of surface cracking (Roy et al., 1996). Surfactant treatment caused lenticel injury, however, which is consistent with previous observations that higher surfactant concentration $(>2 \%)$ caused tissue discoloration of fruit peel in both apples and pears after only a few days at $-\left(0{ }^{\circ} \mathrm{C}\right)$ (Curry, unpublished data). It is interesting that $10 \%$ oil emulsion containing the same concentration of Tween 60 did not cause fruit injury, indicating 


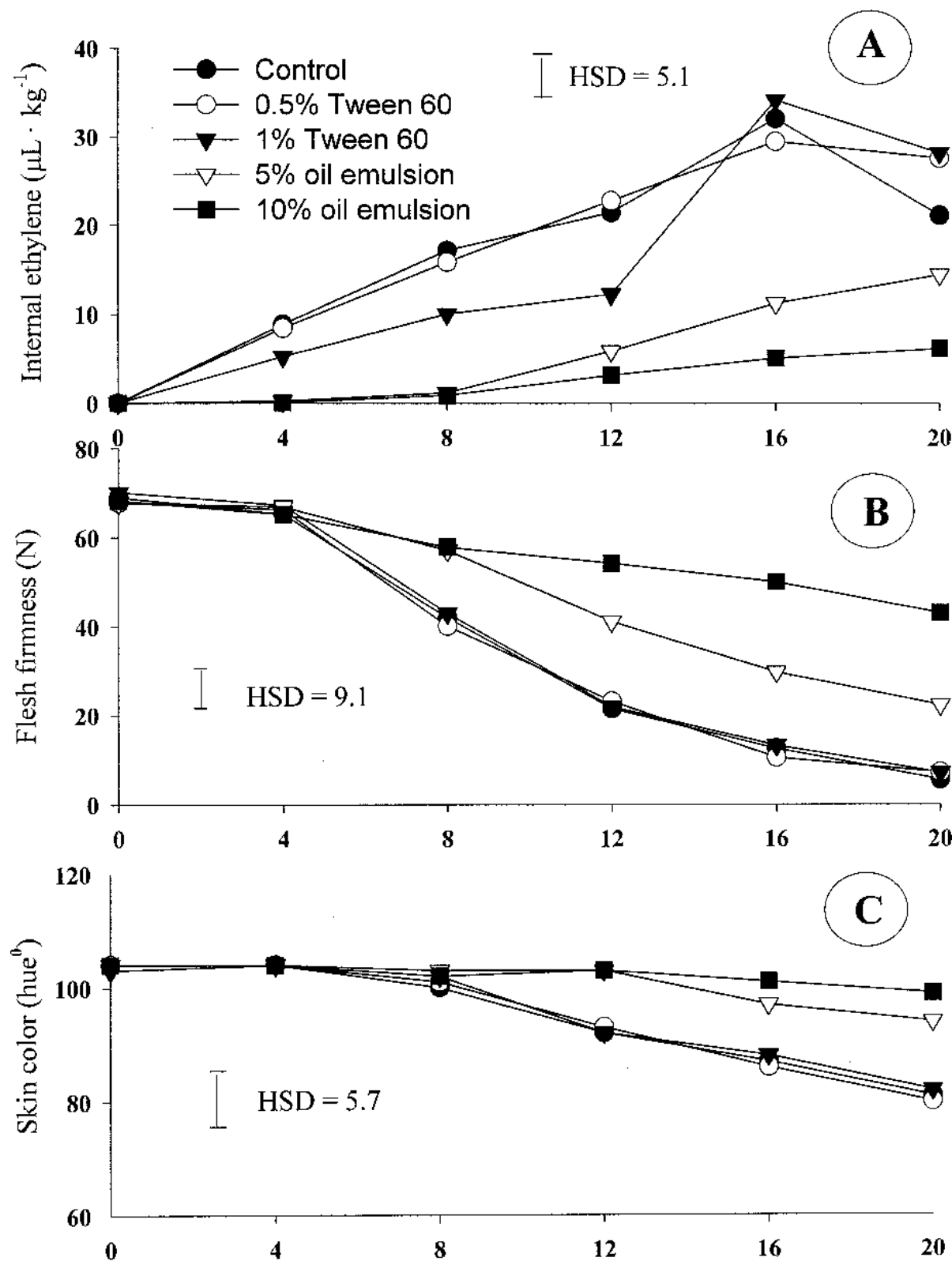

Day at $20^{\circ} \mathrm{C}$
Fig. 3. Effects of Tween 60 and corn oil emulsion on (A) internal ethylene concentration, (B) flesh firmness, and (C) skin color in 'Bartlett' pears stored at $20^{\circ} \mathrm{C}$ for $20 \mathrm{~d}$.

the phytotoxicity of the surfactant was lessened by the presence of plant oil.

The mechanism of decay reduction by oil treatment is unclear. Plant oils do not posses a fungicidal function in and of themselves and in previous studies did not inhibit spore germination in in vitro trials (Duan et al., 2000). Therefore, the reduction in severity of fruit decay by plant oils may be merely through its effects on fruit senescence rather than on pathogen viability. Ethylene stimulates germination of some postharvest pathogens including Botrytis cinerae (pers.) ex Fr. (El-Kazzas et al., 1983) and the susceptibility of fruit to pathogen infection and decay increases with fruit maturity, ripening, and senescence (Boonyakiat et al., 1987; Roberts, 1994; Sommer, 1982). Plant oil treatment inhibits ethylene production in early storage, which may reduce pathogen germination on one hand, and maintain high resistance of fruit to pathogen infection on the other. In addition, controlled or modified atmospheres enriched with $\mathrm{CO}_{2}$ higher than $12 \mathrm{kPa}$ have antifungal properties (Kader et al., 1982; Sommer, 1985). High levels of $\mathrm{CO}_{2}(15 \mathrm{kPa})$ have been reported to be effective in controlling brown rot (Monilinia fructicola) in nectarines [Prunus persica (L.) Batsch (nectarine Group)] (Ahmadi et al., 1999). Therefore, modified internal atmosphere may also be involved in the reduction of decay in oil-treated fruit. In commercial practice, oil treatment may have another advantage over nontreated fruit.

Fig. 4 (below). Scanning electron micrographs of 'Bartlett' pear lenticels from different sections of the same fruit. (A) Nontreated sections and (B) sections treated with $10 \%$ corn oil. Treatment was applied shortly after harvest and the fruit was held for $21 \mathrm{~d}$ at $0{ }^{\circ} \mathrm{C}$.

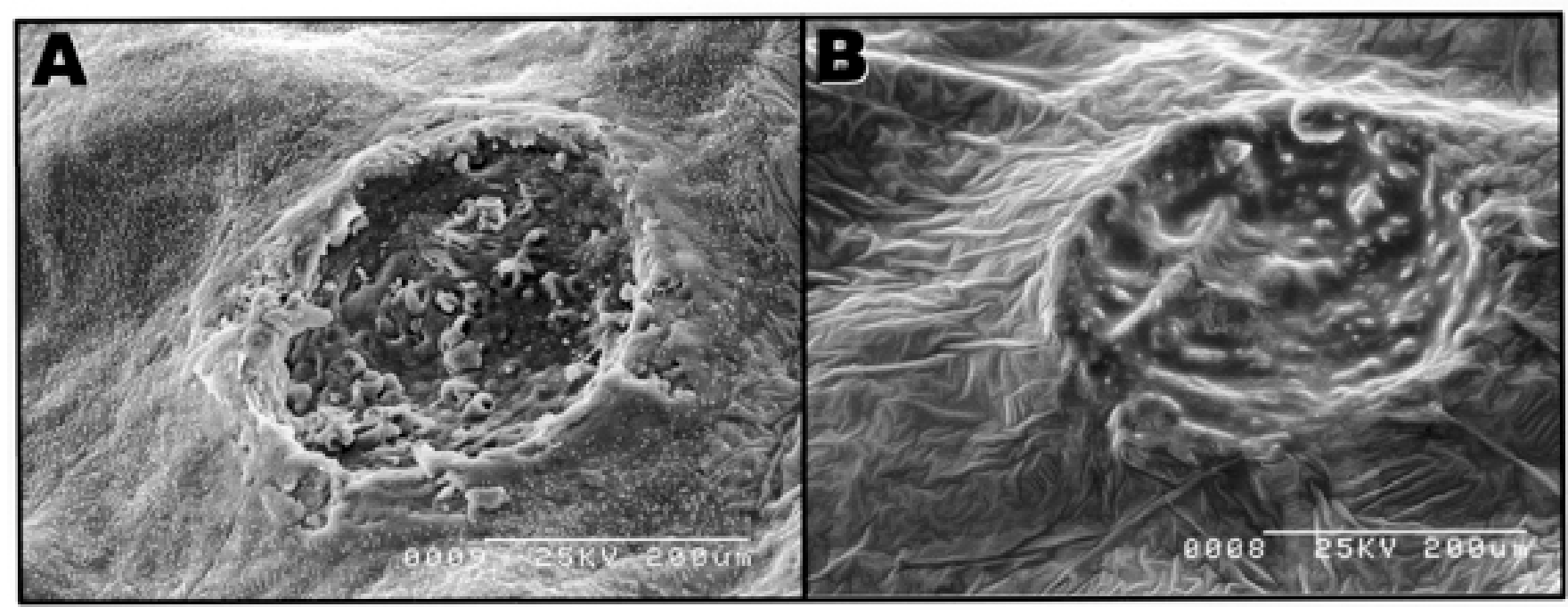


Coating fruit with wax has been recognized to impart lubrication effects to fruit (Lidster, 1981; Mellenthin et al., 1982). It is likely that plant oil has similar effects and therefore, may reduce abrasive or mechanical damage as well as the accompanying pathogenic infection during handling.

\section{Literature Cited}

Ahmadi, H., W.V. Biasi, and E.J. Mitcham. 1999. Control of brown rot decay of nectarines with $15 \%$ carbon dioxide atmospheres. J. Amer. Soc. Hort. Sci. 124:708-712.

Aked, J. 1997. The future of postharvest chemicals. Postharvest News Info. 8:19N-44N.

Beyer, E.M. and P.W. Morgan. 1970. A method for determining the concentration of ethylene in the gas phase of vegetative tissues. Plant Physiol. 46:352-354.

Blanpied, G.D. 1975. Core breakdown of New York 'Bartlett' pears. J. Amer. Soc. Hort. Sci. 100:198-200.

Boonykiat, D., P.M. Chen, R.A. Sportts, and D.G. Richardson. 1987. Effects of harvest maturity on decay and post-harvest life of 'd'Anjou' pear. Scientia Hort. 31:131-139.

Duan, Y., Z. Ju, L. Ju, and A. Guo. 2000. Edible plant oil emulsions control fruit decay in 'Delicious' apples and 'Ya Li' pears. HortScience 35:389 (abstr.).

El-Kazzas, M.K., N.F. Sommer, and A.A. Kader. 1983. Ethylene effects on in vitro and in vivo growth of certain postharvest fruit-infecting fungi. Phytopathology 73:999-1001.

Hagenmaier, R.D., and P.E., Shaw. 1992. Gas permeability of fruit coating waxes. J. Amer. Soc. Hort. Sci. 117:105-109.

Ju,Z. and E.A. Curry. 2000. Stripped corn oil alters ripening, and reduces scald and core flush in 'Granny Smith' apples and scald and decay in 'd'Anjou' pears. Postharvest Biol. Technol. 20:185-193.

Ju, Z., Y. Duan, and Z. Ju. 2000. Mono-, di-, and tri-acylglycerols and phospholipids from plant oils inhibit scald development in 'Delicious' apples. Postharvest Biol. Technol. 19:1-7.

Kader, A.A., M.A. El-Goorani, and N.F. Sommer. 1982. Postharvest decay, respiration, ethylene production, and quality of peaches held in controlled atmospheres with added carbon monoxide. J. Amer. Soc. Hort. Sci. 107:856-859.

Kupferman, E. 1998. Postharvest applied chemicals to pears: A survey of pear packers in Washington, Oregon, and California. Tree Fruit Postharvest J. 9:3-24.

Lidster, P.D., 1981. Some effects of emulsifiable coatings on weight loss, stem discoloration, and surface damage disorders in 'Van' sweet cherries. J. Amer. Soc. Hort. Sci. 106:478-480.

Maguire, K.M., A. Lang, N.H. Banks, A. Hall, D. Hopcroft, and R. Bennett. 1999. Relationship between water vapor permeance of apples and microcracking of the cuticle. Poatharvest Biol. Technol. 17:89-96.

Meheriuk, M. 1990. Effects of diphenylamine, gibberellic acid, daminozide, calcium, high $\mathrm{CO}_{2}$ and elevated temperatures on quality of stored 'Bartlett' pears. Can. J. Plant Sci. 70:887-892.

Meheriuk, M., R.K. Prange, P.D. Lidster, and S.W. Porritt. 1994. Postharvest disorders of apples and pears. Agr. Can. Publ. 1737/E.

Mellenthin, W.M., P.M. Chen, and D.M. Borgic. 1982. In-line application of porous wax coating materials to reduce friction discoloration of 'Bartlett' and 'd'Anjou' pears. HortScience 12:215-217.

National Research Council. 1987. Regulating pesticides in food-The Delaney paradox. Board of Agr., Natl. Res. Council. Natl. Acad. Press, Wash., D.C.

Roberts, R.G. 1994. Integrating biological control into postharvest disease management strategies. HortScience 29:758-762.

Roy, S., W.S. Conway, J.G. Buta, A.E. Watada, C.E. Sams, and W.P. Wergin. 1996. Surfactants affect calcium uptake from postharvest treatment of 'Golden Delicious' apples. J. Amer. Soc. Hort. Sci. 121:1179-1184.

Saftner, R.A. 1999. The potential of fruit coating and film treatments for improving the storage and shelf-life qualities of 'Gala' and 'Golden Delicious' apples. J. Amer. Soc. Hort. Sci. 124:682-689.

Sommer, N.F. 1982. Postharvest handling practices and postharvest diseases of fruit. Plant Dis. 66:357-364.

Sommer, N.F. 1985. Role of controlled environments in suppression of postharvest diseases. Can. J. Plant Pathol. 7:331-339. 